\title{
Jenis Proposisi Dalam Karangan Argumentasi Siswa
}

\author{
Syahruddin $^{1}$, Sumadi $^{1}$, Sunaryo $^{1}$ \\ ${ }^{1}$ Pendidikan Bahasa Indonesia-Universitas Negeri Malang
}

\begin{tabular}{l}
\hline \hline INFO ARTIKEL \\
\hline Riwayat Artikel: \\
Diterima: 09-05-2019 \\
Disetujui: 26-05-2019 \\
\hline
\end{tabular}

\section{Kata kunci:}

\section{proposition;}

argumentation essay;

high school student;

proposisi;

karangan argumentasi,

siswa SMA

\begin{abstract}
This research was aimed to describe the type of proposition on argumentative text of students. This study is a text analysis study. The data of the study was the sentence of students' argumentative text. The data has been analyzed by structural syntactic studies and semantic logic. The result of the study shows that the type of proposition on students' argumentative text are (1) type of proposition based on the source, (2) type of proposition based on the shape, (3) type of proposition based on the character, (4) type of proposition based on the level of certainty of truth, (5) type of proposition based on the quality, (6) type of proposition based on the quantity, and (7) type of proposition based on the combination of quantity and quality.
\end{abstract}

ABSTRAK

\begin{abstract}
Abstrak: Penelitian ini bertujuan mendeskripsikan jenis proposisi dalam karangan argumentasi siswa. Jenis penelitian ini adalah analisis teks. Data dan sumber data dalam penelitian berupa kalimat-kalimat dalam karangan argumentasi siswa. Data akan dianalisis dengan kajian sintaksis struktural dan logika semantikal. Hasil penelitian ditemukan jenis proposisi dalam karangan argumentasi siswa, meliputi (1) jenis proposisi berdasarkan sumbernya, (2) jenis proposisi berdasarkan bentuknya, (3) jenis proposisi berdasarkan sifatnya, (4) jenis proposisi berdasarkan tingkat kepastian kebenaran (5) jenis proposisi berdasarkan kualitasnya, (6) jenis proposisi berdasarkan kuantitasnya, dan (7) jenis proposisi berdasarkan kombinasi kuantitas dan kualitasnya.
\end{abstract}

\author{
Alamat Korespondensi: \\ Syahruddin \\ Pendidikan Bahasa Indonesia \\ Universitas Negeri Malang \\ Jalan Semarang 5 Malang \\ E-mail: syahruddinspdmts@gmail.com
}

Kompetensi lulusan mata pelajaran bahasa Indonesia SMA/MA adalah menjadi insan yang memiliki kemampuan berbahasa dan bersastra serta menerapkannya secara kreatif dalam kehidupan sosial. Kemampuan berbahasa yang dimaksud meliputi kemampuan mendengarkan, membaca, memirsa (viewing), berbicara dan menulis (Kemendikbud, 2017). Secara umum, dalam pembelajaran bahasa Indonesia, terbagi dua kemampuan utama, yaitu kompetensi memahami (comprehension) dan mempergunakan (production), masing-masing bersifat reseptif dan produktif. Kemampuan reseptif merupakan proses decoding, yaitu proses untuk memahami apa yang dituturkan oleh orang lain, meliputi kompetensi membaca dan menyimak. Sementara itu, kemampuan produktif merupakan proses encoding, yaitu proses mengomunikasikan ide, pikiran, atau perasaan melalui bentukbentuk kebahasaan, meliputi kompetensi berbicara dan menulis (Nurgiyantoro, 2016). Salah satu objek yang dapat mengukur kemampuan siswa dalam pemahaman konsep dan pertimbangan adalah melalui ekspresi verbal dalam membuat proposisi.

Proposisi dapat diartikan sebagai pernyataan yang memuat gagasan utuh yang digunakan untuk menyatakan konsep atau menandai kebenaran atau kesalahan tentang sesuatu (Dawud, 1998). Proposisi sebagai entitas pembawa kebenaran memainkan peran utama dalam filsafat bahasa kontemporer. Proposisi berperan sebagai pembentuk makna kalimat, dan objek dari sikap proposisional yang independen (Moltmann, 2013). Menurut ilmu logika, proposisi sebagai unsur kegiatan akal budi tingkat kedua. Kegiatan mempersatukan dua term tersebut berupa menciptakan hubungan meneguhkan atau hubungan mengingkari subjek kalimatnya. Hubungan kedua term ini menghasilkan penilaian berupa apakah kedua konsep ini sama atau tidak, atau apakah konsep yang satu termasuk ke dalam konsep yang lain atau tidak. Proses tersebut menghasilkan sebuah putusan yang nantinya akan diwujudkan dalam sebuah proposisi. Mengingat peran proposisi tersebut, maka penelitian ini memfokuskan pada kemampuan siswa dalam berpikir logis, yang dapat dinilai benar atau salah pada karangan argumentasi.

Secara fungsional, proposisi menjadi bagian dari ilmu logika dapat dirunut pada setiap tataran kebahasaan, yaitu frasa, klausa, kalimat, dan wacana. Tataran kebahasan tersebut dalam wujudnya selalu disampaikan dalam ekspresi verbal berwujud tuturan atau perkataan. Proses mengungkapkan gagasan tersebut selalu melibatkan bahasa dan pikiran. Pertama, pikiran memengaruhi bahasa, yaitu bahasa sebagai alat mempersepsi, memproduksi bahasa untuk memperoleh kecakapan berpikir dengan lurus. Kedua, bahasa memengaruhi pikiran, yaitu untuk dapat berpikir lurus, memerlukan pemakaian kata-kata yang tepat pula. Jadi, antara pemikiran dan bahasa terdapat suatu hubungan timbal balik (Poespoprodjo dan Gilarso, 2017). Hasil pemikiran dalam logika, seperti diuraikan tersebut merupakan kegiatan akal budi manusia. Terdapat tiga langkah kegiatan akal budi manusia, yaitu 
(1) pemahaman sederhana (simple apprehension) yang menghasilkan konsep atau definisi, (2) membuat keputusan (judgment) yang menghasilkan proposisi, dan (3) penalaran (reasoning) yang menghasilkan argumen atau argumentasi (Sidharta, 2016).

Argumentasi adalah suatu bentuk retorika yang berusaha untuk memengaruhi sikap dan pendapat orang lain, agar mereka percaya dan akhirnya bertindak sesuai dengan apa yang diinginkan oleh penulis (Keraf, 2007). Argumentasi termasuk dalam tindak akal budi ketiga berupa penyusunan simpulan untuk memperoleh pengetahuan baru yang didasarkan pada kebenaran yang telah diketahui sebelumnya. Munculnya argumentasi ini karena adanya aktivitas manusia yang sangat khas, yaitu tindak berpikir. Kegiatan berpikir lebih mengedepankan penggunaan akal sehat dan penalaran yang baik sehingga memunculkan bahasa yang logis. Hasil dari kegiatan berargumentasi dapat berupa argumen. Argumen merupakan seperangkat pernyatan yang berupa pendirian dan didukung oleh bukti-bukti terhadap pendirian tersebut (Dawud, 2010). Argumentasi bukan deskripsi tentang bagaimana kita bisa berpikir, melainkan sebuah aturan yang normatif bagaimana seharusnya kita berpikir (Adian dan Pratama, 2015). Semakin baik tindak berpikir seseorang, maka akan semakin baik pula argumen dan proposisi yang dihasilkannya.

Penelitian yang berkaitan dengan proposisi sudah pernah dilakukan. Dawud (1998) melakukan penelitian dengan judul Penalaran dalam Tuturan Bahasa Indonesia Siswa Sekolah Dasar. Penelitian ini mengkaji tindak dan wujud penalaran dalam tuturan bahasa Indonesia lisan siswa sekolah dasar. Suyitno (2005) melakukan penelitian dengan judul Proposisi Bentuk Kosong dalam Wacana Slogan: Kajian Tindak Tutur Wacana Slogan. Penelitian ini mengkaji proposisi bentuk kosong berdasarkan kajian tindak tutur dalam wacana slogan. Narimo (2014) melakukan penelitian yang berjudul Proposisi dan Argumen dalam Diskusi Kelas Siswa SMP. Penelitian ini memfokuskan pada bentuk proposisi dan argumen bahasa lisan dalam kegiatan diskusi siswa SMP. Amaliah, Ghazali, \& Hasanah (2015) melakukan penelitian dengan judul Proposisi Puisi Karya Anak. Penelitian ini mengkaji pemakaian proposisi pada puisi karya anak sekolah dasar berdasarkan tinjauan semantik. Objek penelitian yang dilakukan oleh Amaliah adalah puisi yang ditulis oleh anak.

Berbeda dengan kajian tersebut, penelitian ini mengkaji jenis proposisi yang muncul dalam karangan argumentasi siswa kelas XI MAN 2 Wakatobi. Pendeskripsian jenis proposisi tersebut mengacu pada klasifikasi jenis proposisi dari sudut pandang logika. Jenis proposisi mengacu pada sebuah konsep (kata, term, dan konsep) saling berhubungan satu sama lain sehingga membentuk kumpulan kata, kumpulan term, serta kumpulan definisi yang telah diklasifikasi sedemikian rupa sehingga membentuk sebuah kalimat yang mengandung arti penuh dan utuh (Ranjabar, 2017). Jenis proposisi pada dasarnya mengacu pada struktur proposisi yang mengatur pada struktur luar dan struktur dalam bahasa dengan pola-pola tertentu sebagai hasil ekspresi verbal penutur (Narimo, 2014). Pengklasifikasian jenis proposisi merupakan kegiatan membagi jenis proposisi berdasarkan sudut pandang tertentu. Klasifikasi jenis proposisi tersebut berdasarkan sumbernya, bentuknya, sifatnya, tingkat kepastian kebenaran (modalitas), kualitasnya, kuantitasnya, dan kombinasi kuantitas dan kualitasnya (Martono dan Shodiq, 2018).

Berdasarkan pertimbangan tersebut, sangat diperlukan kajian jenis proposisi dalam karangan siswa kelas XI MAN 2 Wakatobi. Jenis proposisi diharapkan dapat menggambarkan kompetensi bernalar atau berpikiran logis. Kegiatan berpikir tersebut merupakan kegiatan akal untuk mengolah pengetahuan yang telah kita terima melalui panca indera untuk mencapai suatu kebenaran (Poespoprodjo dan Gilarso, 2017). Berpikir logis juga merupakan modal dasar siswa untuk dapat berpikir dan bertindak secara bijak terutama dalam pengambilan sebuah keputusan. Hal ini sejalan dengan tujuan argumen untuk meyakinkan dan memengaruhi orang lain dengan memberikan alasan berupa data-data, bukti-bukti tertentu yang dicapai melalui pembelajaran menulis karangan argumentasi. Kompetensi bernalar melalui jenis proposisi ini sangat penting karena berhubungan dengan kegiatan pikiran atau akal budi manusia yang tercermin dalam performansi berbahasa.

\section{METODE}

Pendekatan penelitian ini adalah pendekatan kualitatif, sedangkan jenis penelitian ini adalah analisis teks. Data penelitian ini adalah kalimat-kalimat dalam karangan argumentasi dan sumber datanya adalah karangan argumentasi siswa kelas XI MAN 2 Wakatobi. Data berupa kalimat tersebut akan diidentifikasi yang berdasarkan jenis proposisi yang digunakan oleh siswa dalam karangan argumentasinya. Jenis analisis data yang digunakan dalam penelitian ini adalah pendekatan linguistik struktural dan logika. Rincian karangan yang dikumpulkan sebagai data penelitian mencakup seluruh karangan argumentasi siswa kelas XI IPA dan IPS MAN 2 Wakatobi yang berjumlah 48 orang. Pengumpulan data dilakukan dengan teknik penugasan penulisan karangan argumentasi pada siswa. Setelah data terkumpul, data dianalisis menggunakan teknik analisis data dengan model yang dikembangkan oleh (Miles dan Huberman, 1994) meliputi (1) reduksi data, (2) penyajian data, dan (3) penarikan kesimpulan dan verifikasi.

\section{HASIL}

Jenis proposisi dalam karangan argumentasi siswa MAN 2 Wakatobi ini dianalisis berdasarkan (1) sumbernya, (2) bentuknya, sifatnya, (4) tingkat kepastian kebenaran, (5) kualitasnya, (6) kuantitasnya, dan (7) kombinasi kuantitas dan kualitasnya. Hasil analisis selengkapnya disajikan berikut.

Pertama, berdasarkan sumbernya, proposisi dalam karangan argumentasi siswa Kelas XI MAN 2 Wakatobi ada yang berjenis (1) proposisi analitis (PA) dan (2) proposisi sintesis (PS). Proposisi berjenis analitis dalam karangan argumentasi siswa seperti pada data Membaca adalah kunci ilmu pengetahuan (JPBS-PA:48.01). Proposisi berjenis sintesis dalam karangan argumentasi siswa seperti pada data Pendidikan bermutu itu mahal (JPBS-PS:20.18). 
Kedua, berdasarkan bentuknya, proposisi dalam karangan argumentasi siswa Kelas XI MAN 2 Wakatobi ada yang berjenis (1) proposisi tunggal (PT), dan (2) proposisi majemuk (PM). Proposisi berjenis tunggal dalam karangan argumentasi siswa seperti pada data Kita harus tetap giat membaca (JPBB-PT:48.42). Proposisi berjenis majemuk dalam karangan argumentasi siswa seperti pada data Buku-buku ini bisa kita koleksi dan bisa dibaca sewaktu-waktu (JPBB-PM: 48.34).

Ketiga, berdasarkan sifatnya, proposisi dalam karangan argumentasi siswa kelas XI MAN 2 Wakatobi ada yang berjenis (1) proposisi kategoris (PK), (2) proposisi hipotesis kondisional (HK), (3) proposisi hipotesis disjungtif (HD), dan (4) proposisi hipotesis konjungtif $(\mathrm{HJ})$. Proposisi berjenis kategoris dalam karangan argumentasi siswa seperti pada data Handphone telah menyebabkan perkembangan anak terganggu (JPBT-PK:36.05). Proposisi berjenis hipotesis kondisional dalam karangan argumentasi siswa seperti pada data Jika seseorang ingin menjadi muslim sejati, maka ia harus meyakini Islam sebagai agama yang benar (JPBT-HK: 07.08). Proposisi berjenis hipotesis disjungtif dalam karangan argumentasi siswa seperti pada data Banjir, tanah longsor merupakan permasalahan pemerintah daerah atau pemerintah pusat (JPBT-HD: 6.05). Proposisi berjenis hipotesis konjungtif dalam karangan argumentasi siswa seperti pada data Amal perbuatan manusia di dunia berupa perbuatan baik dan perbuatan buruk (JPBT-HJ: 07.08).

Keempat, berdasarkan tingkat kepastian kebenaran (modalitas), proposisi dalam karangan argumentasi siswa kelas XI MAN 2 Wakatobi ada yang berjenis (1) proposisi berjenis modalitas mutlak (MM), (2) proposisi berjenis modalitas kontingen (MK), (3) proposisi berjenis modalitas mungkin (MU), dan (4) proposisi berjenis modalitas yang tidak mungkin (TM). Proposisi berjenis modalitas mutlak dalam karangan argumentasi siswa seperti pada data Handphone adalah alat komunikasi secara tidak langsung (JPBK-MM:36.01). Proposisi berjenis modalitas kontingen dalam karangan argumentasi siswa seperti pada data Pemerintah telah menetapkan negara kita sedang berada dalam keadaan darurat narkoba (JPBK-MK:07.08). Proposisi berjenis modalitas mungkin dalam karangan argumentasi siswa seperti pada data Internet akan mempermudah mengakses berbagai informasi secara internasional (JPBK-MU:26.30). Proposisi berjenis modalitas tidak mungkin dalam karangan argumentasi siswa seperti pada data Seekor ikan tidak dapat dipaksa memanjat pohon atau berlari karena Tuhan menciptakan ia untuk berenang di air (JPBT-HJ:07.08).

Kelima, berdasarkan kualitasnya, proposisi dalam karangan argumentasi siswa kelas XI MAN 2 Wakatobi ada yang berjenis (1) proposisi positif (PP), dan (2) proposisi negatif (PN). Proposisi positif dalam karangan argumentasi siswa seperti pada data Agama Islam adalah agama yang mendominasi warga negara Indonesia (JPBL-PP:26.02). Proposisi berjenis negatif dalam karangan argumentasi siswa seperti pada data Kita tidak mempedulikan keadaan lingkungan (JPBL-PN:33.05).

Keenam, berdasarkan kuantitasnya, proposisi dalam karangan argumentasi siswa kelas XI MAN 2 Wakatobi ada yang berjenis (1) proposisi universal (PU), (2) proposisi partikular (PK), dan (3) proposisi singular (PS). Proposisi berjenis universal dalam karangan argumentasi siswa seperti pada data Semua mahluk hidup di bumi membutuhkan perawatan (JPBN-PU:01.01). Proposisi berjenis partikular dalam karangan argumentasi siswa, seperti pada data Sebagian pelajar yang kurang memperhatikan pelajarannya (JPBN-PK:27.28). Proposisi berjenis singular dalam karangan argumentasi siswa seperti pada data Kepala sekolah kami sudah menginstruksikan penerapan aturan sekolah dengan segala sanksi-sanksinya (JPBK-PS:39.19).

Ketujuh, berdasarkan kombinasi kuantitas dan kualitasnya, proposisi dalam karangan argumentasi siswa kelas XI MAN 2 Wakatobi ada yang berjenis (1) proposisi universal afirmatif (UA), (2) proposisi partikular afirmatif (PA), (3) proposisi singular afirmatif (SA), (4) proposisi universal negatif (UN), (5) proposisi partikular negatif (PN), dan (6) proposisi singular negatif (SN). Proposisi berjenis universal afirmatif dalam karangan argumentasi siswa seperti pada data Semua pengguna jalan memiliki kewajiban untuk menaati peratiran lalu lintas (JPBM-UA:17.04). Proposisi berjenis partikular afirmatif dalam karangan argumentasi siswa seperti pada data Kondisi sebagian umat Islam yang kita lihat saat ini sangat menyedihkan (JPBM-PA: 07.09). Proposisi berjenis singular afirmatif dalam karangan argumentasi siswa seperti pada data Indonesia merupakan negara yang memiliki iklim tropis (JPBM-SA:01.14). Proposisi berjenis universal negatif dalam karangan argumentasi siswa seperti pada data Seтиa siswa tidak boleh meninggalkan lingkungan sekolah selama jam pelajaran berlangsung (JPBM-UN:12.14). Proposisi berjenis partikular negatif dalam karangan argumentasi siswa seperti pada data Seorang muslim tidak akan tersesat selama mereka berpegang teguh kepada alquran dan alhadis (JPBM-PN: 07.19) Proposisi berjenis singular negatif dalam karangan argumentasi siswa seperti pada data Ketua Osis kami tidak menyampaikan laporan pertanggungjawaban akhir tahun (JPBM-SN:22.34).

\section{PEMBAHASAN}

\section{Proposisi Berdasarkan Sumbernya}

Berdasarkan sumbernya dalam karangan argumentasi siswa kelas XI MAN 2 Wakatobi ditemukan proposisi berjenis (1) proposisi analitis, dan (2) proposisi sintesis. Proposisi analitis dapat dijelaskan dengan contoh kalimat Membaca adalah kunci ilmu pengetahuan. Term subjek membaca berarti usaha untuk memahami isi dari apa yang tertulis, sedangkan term predikat kunci ilmu pengetahuan adalah segala sesuatu yang diketahui berkenaan dengan ilmu pengetahuan. Antara term subjek dan term predikat tidak terdapat hubungan pertentangan dalam pernyataannya. Proposisi analitis ini terdapat bagian yang menunjukkan arti yang sama pada bagian lain yang tersusun (Zaimul, 2000). Proposisi yang predikatnya memiliki pengertian yang sudah terkandung pada term subjeknya disebut proposisi analitis (Djoko, 2011; Ranjabar, 2017). Proposisi sintesis dapat dijelaskan dengan contoh kalimat Pendidikan bermutu itu mahal. Term subjek pendidikan bermutu itu merupakan proses pengubahan sikap dan tata laku seseorang melalui upaya pengajaran atau pelatihan yang berkualitas, sedangkan term predikat mahal yang berarti harganya sangat tinggi. FN pendidikan bermutu itu memiliki makna yang berbeda dengan yang dinyatakan oleh predikatnya mahal. Proposisi 
analitis ini tidak terdapat bagian yang menunjukkan arti yang sama pada bagian lain yang tersusun (Zaimul, 2000). Proposisi yang term predikatnya tidak menjadi keharusan bagi term subjeknya disebut proposisi analitis (Djoko, 2011; Ranjabar, 2017). Argumen ini berdasarkan kenyataan empiris bahwa pada kenyataannya pendidikan bermutu itu merupakan pendidikan yang baik dan berkualitas. Kedua contoh kalimat tersebut mengungkapkan satu pendirian. Sebuah pendirian harus meneguhkan atau menyangkal suatu hubungan antara dua pernyataan (Poespoprodjo dan Gilarso, 2017; Sidharta, 2016). Temuan ini menunjukkan bahwa siswa sudah mampu menggunakan jenis proposisi sintesis dan analitis dalam karangan argumentasi siswa secara bervariasi.

\section{Proposisi Berdasarkan Bentuknya}

Berdasarkan bentuknya dalam karangan argumentasi siswa kelas XI MAN 2 Wakatobi ditemukan proposisi berjenis (1) proposisi tunggal dan (2) proposisi majemuk. Proposisi tunggal tersebut dapat dijelaskan dengan contoh kalimat Kita harus tetap giat membaca. Proposisi berjenis kalimat tunggal ini hanya mengandung atas satu pernyataan dan didukung oleh satu subjek dan satu predikat (Martono \& Shodiq, 2018; Ranjabar, 2017). Proposisi tunggal ini juga dikenal sebagai proposisi sederhana yaitu proposisi yang hanya memiliki satu subjek dan satu predikat atau lebih dikenal dengan proposisi subjek-predikat (Sidharta, 2016; Sumadi, 2013). Proposisi berjenis kalimat tunggal yang dibentuk atas satu klausa independen tunggal dengan unsur wajib subjek dan predikat ditambah dua atau tiga unsur lain disebut kalimat tunggal (Demirezen, 2013). Proposisi berdasarkan bentuknya dalam karangan argumentasi siswa kelas XI MAN 2 Wakatobi ditemukan proposisi berjenis majemuk. Proposisi majemuk tersebut dapat dijelaskan dengan contoh kalimat Buku-buku ini bisa kita koleksi dan bisa dibaca sewaktu-waktu. Proposisi yang mengandung dua pernyataan dan didukung oleh dua proposisi tunggal disebut proposisi majemuk (Ranjabar, 2017). Proposisi ini merupakan gabungan dua proposisi tunggal atau lebih yang didukung oleh dua pola kalimat (Martono dan Shodiq, 2018). Secara semantis proposisi majemuk ini memiliki hubungan antarklausa koordinatif karena tidak ada klausa yang dianggap lebih penting (Setiawan, 2019). Kedua contoh kalimat tersebut mengungkapkan satu pendirian. Sebuah pendirian harus meneguhkan atau menyangkal suatu hubungan antara dua pernyataan (Poespoprodjo dan Gilarso, 2017; Sidharta, 2016). Temuan ini menunjukkan bahwa siswa sudah mampu menggunakan jenis proposisi tunggal dan proposisi majemuk dalam karangan argumentasi siswa secara bervariasi.

\section{Proposisi Berdasarkan Sifatnya}

Berdasarkan sifatnya dalam karangan argumentasi siswa kelas XI MAN 2 Wakatobi ditemukan proposisi berjenis (1) proposisi kategoris, (2) proposisi hipotesis kondisional, (3) proposisi hipotesis disjungtif, dan (4) proposisi hipotesis konjungtif. Proposisi kategoris dapat dijelaskan dengan contoh kalimat Handphone telah menyebabkan perkembangan anak terganggu. Proposisi ini terdiri atas satu pernyataan yang tersusun atas unsur term subjek handphone, term predikat menyebabkan, dan fungsi objek perkembangan anak terganggu. Penghubung tersebut berfungsi memberikan warna atau corak terhadap suatu putusan (Djoko, 2011). Proposisi ini dapat menyampaikan makna yang utuh tanpa bergantung pada proposisi lain (Suyitno, 2008). Hal ini berarti bahwa hubungan antara term subjek dan term predikat tanpa suatu syarat tertentu. Proposisi yang mengandung pernyataan bebas tanpa adanya syarat disebut proposisi kategoris (Martono dan Shodiq, 2018; Ranjabar, 2017).

Proposisi hipotesis kondisional dapat dijelaskan dengan contoh kalimat Jika seseorang ingin menjadi muslim sejati, maka ia harus meyakini Islam sebagai agama yang benar. Proposisi ini terdiri atas dua pernyataan bersyarat jika seseorang ingin menjadi muslim sejati, sebagai proposis anteseden mengungkapkan sebab (syarat), dan maka ia harus meyakini Islam sebagai agama yang benar mengungkapkan akibat disebut proposisi konsekuen. Kedua unsur yang berupa sebab dan akibat disatukan dengan penghubung jika dan maka. Proposisi tersebut menunjuk pada pembenaran bersyarat yaitu jika oposisinya terpenuhi (sebab-akibat) maka kebenaran dapat terjadi (Suyitno, 2008). Sebuah proposisi yang menunjuk pada kebenaran bersyarat dan mengandung dugaan atau prediksi dan menyebutkan hubungan sebab akibat disebut proposisi hipotesis kondisional (Ibrahimi, 2012; Martono dan Shodiq, 2018; Ranjabar, 2017). Proposisi hipotesis disjungtif dapat dijelaskan dengan contoh kalimat Banjir, tanah longsor, dan lain-lain itu merupakan permasalahan pemerintah daerah atau pemerintah pusat. Proposisi ini terdiri atas dua pernyataan kategoris banjir, tanah longsor, dan lain-lain itu merupakan permasalahan pemerintah daerah dan banjir, tanah longsor, dan lain-lain itu merupakan permasalahan pemerintah pusat. Kedua proposisi ini mengungkapkan bahwa pada waktu yang bersamaan dua buah proposisi tidak dapat kedua-duanya benar atau kedua-duanya salah. Kedua proposisi dalam pernyataan di atas, dihubungkan dengan konjungsi atau menjadikan dua proposisi kategoris tersebut menjadi proposisi disjungtif. Proposisi disjungtif tersebut mengandung pernyataan yang menyatakan kebenaran berupa pilihan antara dua atau lebih (Martono dan Shodiq, 2018; Ranjabar, 2017).

Proposisi hipotesis disjungtif akan bernilai salah hanya jika proposisi elementernya salah (Suyitno, 2008). Proposisi hipotesis konjungtif dapat dijelaskan dengan contoh kalimat Amal perbuatan manusia di dunia berupa perbuatan baik dan perbuatan buruk. Proposisi ini terdiri atas pernyataan hipotesis proposisi kategoris. Kedua proposisi ini mengungkapkan bahwa pada waktu yang bersamaan dua buah proposisi tidak dapat kedua-duanya benar atau kedua-duanya salah. Kedua proposisi dalam pernyataan di atas, dihubungkan dengan konjungsi dan yang menjadikan dua proposisi kategoris tersebut menjadi proposisi konjungtif. Proposisi konjungtif tersebut merupakan gabungan dua pernyataan kontradiktif yang mengandung kebenaran yang tidak sama dan dalam waktu yang bersamaan disebut proposisi hipotesis konjungtif (Martono dan Shodiq, 2018). Proposisi hipotesis konjungtif akan bernilai benar hanya jika kedua proposisi elementernya benar (Suyitno, 2008). Kehadiran penghubung berupa dalam proposisi tersebut berfungsi sebagai penanda yang meneguhkan proposisi kalimatnya. Kalimat-kalimat tersebut 
juga mengandung sebuah argumen yang berupa pendirian (claim) dan landasan (ground). Sebuah pendirian harus meneguhkan atau menyangkal suatu hubungan antara dua pernyataan (Poespoprodjo dan Gilarso, 2017; Sidharta, 2016). Temuan ini menunjukkan bahwa siswa sudah mampu menggunakan jenis proposisi kategoris, hipotesis kondisional, hipotesis disjungtif, dan hipotesis konjungtif dalam karangan argumentasi siswa secara bervariasi.

\section{Proposisi Berdasarkan Tingkat Kepastian Kebenaran}

Berdasarkan tingkat kepastian kebenaran dalam karangan argumentasi siswa kelas XI MAN 2 Wakatobi ditemukan proposisi berjenis (1) proposisi modalitas mutlak, (2) proposisi modalitas kontingen, (3) proposisi modalitas mungkin, dan (4) proposisi modalitas tidak mungkin. Proposisi modalitas mutlak dapat dijelaskan dengan contoh kalimat Handphone adalah alat komunikasi secara tidak langsung. Handphone berarti alat komunikasi yang berupa telepon mandiri yang menggunakan baterai, tanpa kabel, dan menerima suara melalui sinyal. Hal ini berarti bahwa term predikat alat komunikasi merupakan hal yang sudah dinyatakan oleh subjeknya handphone. Proposisi yang term predikatnya sudah dinyatakan oleh subjek atau tidak memiliki fungsi yang lain disebut proposisi modalitas mutlak (Martono dan Shodiq, 2018). Predikat dalam proposisi ini sudah menjadi bagian dari subjek tersebut. Hubungan antara term subjek dan term predikat bersifat mutlak. Proposisi berjenis modalitas kontingen dapat dijelaskan dengan contoh kalimat Pemerintah telah menetapkan negara kita sedang berada dalam keadaan darurat narkoba. Proposisi pemerintah telah menetapkan negara kita sedang berada dalam keadaan darurat narkoba merupakan suatu pernyataan yang menyampaikan sebuah kebenaran secara sementara. Keputusan ini tidak berlaku selamanya tetapi hanya untuk saat ini yang berarti untuk masa kurang lebih satu tahun. Proposisi yang menyampaikan maksud berupa kebenaran yang bersifat sementara disebut proposisi modalitas kontingen (Martono dan Shodiq, 2018). Hubungan maksud antara term subjek, term predikat, term objek, dan keterangan bersifat sementara. Sebagai bentuk proposisi modalitas, proposisi ini menggunakan kata-kata yang menyatakan tingkatan-tingkatan kepastian. Kehadiran penghubung sedang dalam proposisi tersebut berfungsi sebagai penanda term predikat yang meneguhkan subjek kalimatnya.

Proposisi modalitas mungkin dapat dijelaskan dengan contoh kalimat Internet akan mempermudah mengakses berbagai informasi secara internasional. Term predikat mempermudah mengakses mengemukakan kemungkinan akan terjadinya sesuatu dari objeknya berbagai informasi. Proposisi yang menyatakan suatu kemungkinan di antara subjek dan predikat disebut proposisi modalitas mungkin (Martono dan Shodiq, 2018). Proposisi ini merupakan proposisi yang sudah menjadi bagian dari subjek tersebut. Kehadiran penghubung akan dalam proposisi tersebut berfungsi sebagai penanda term predikat yang meneguhkan subjek kalimatnya. Proposisi modalitas tidak mungkin dapat dijelaskan dengan contoh kalimat Seekor ikan tidak dapat dipaksa memanjat pohon atau berlari karena Tuhan menciptakan ia untuk berenang di air. Proposisi modalitas yang tidak mungkin tersebut terdiri atas dua proposisi. Term predikat tidak dapat dipaksa mengemukakan penanda term predikat yang mengingkari subjek kalimatnya. Kalimat-kalimat tersebut mengandung sebuah argumen yang ketidakmungkinan akan terjadinya sesuatu dari objek seekor ikan. Seekor ikan tidak mungkin bisa melakukan kegiatan seperti yang dinyatakan oleh predikat dan objeknya yaitu memanjat pohon dan berlari. Proposisi yang menyatakan suatu yang tidak mungkin di antara subjek dan predikat disebut proposisi modalitas yang tidak mungkin (Martono dan Shodiq, 2018). Hubungan maksud antara term subjek, term predikat, term objek, dan keterangan bersifat mustahil. Kehadiran penghubung tidak dalam proposisi tersebut berfungsi sebagai berupa pendirian (claim) dan landasan (ground). Sebuah pendirian harus meneguhkan atau menyangkal suatu hubungan antara dua pernyataan (Poespoprodjo dan Gilarso, 2017; Sidharta, 2016). Temuan ini menunjukkan bahwa siswa sudah mampu menggunakan jenis proposisi modalitas dalam karangan argumentasi siswa secara bervariasi.

\section{Proposisi Berdasarkan Kualitasnya}

Berdasarkan kualitasnya dalam karangan argumentasi siswa kelas XI MAN 2 Wakatobi ditemukan proposisi berjenis (1) proposisi positif, dan (2) proposisi negatif. Proposisi positif dapat dijelaskan dengan contoh kalimat Agama Islam adalah agama yang mendominasi warga negara Indonesia. Term predikat adalah agama yang mendominasi merupakan suatu term yang membenarkan suatu hubungan yang dinyatakan oleh subjek agama Islam. Kedua term tersebut merupakan suatu proposisi yang dinyatakan dalam bentuk satu kesatuan bukan dinyatakan dalam bentuk terpisah. Proposisi positif memiliki sebuah subjek, predikat, kopula, dan kualitas berupa afirmasi (Zaimul, 2000). Sebagai proposisi positif, frasa verba adalah agama yang mendominasi merupakan term proposisi yang bersifat meneguhkan subjek agama Islam. Proposisi yang membenarkan atau mengiyakan adanya kesesuaian hubungan antara subjek dan predikatnya disebut proposisi positif atau proposisi afirmasi (Martono dan Shodiq, 2018; Ranjabar, 2017). Peneguhan ini ditandai oleh tidak adanya penanda negasi tidak pada predikatnya (Sidharta, 2016). Proposisi negatif dapat dijelaskan dengan contoh kalimat Kita tidak mempedulikan keadaan lingkungan. Kedua term tersebut merupakan suatu proposisi yang dinyatakan dalam bentuk terpisah antara termnya. Proposisi negatif memiliki sebuah subjek, predikat, kopula, dan kualitas berupa negasi (Zaimul, 2000). Frasa verba tidak mempedulikan merupakan term proposisi yang bersifat mengingkari subjek kita. Proposisi yang mengingkari kebenaran kesesuaian hubungan antara subjek dan predikatnya disebut proposisi negatif (Martono dan Shodiq, 2018; Ranjabar, 2017). Peneguhan ini ditandai oleh adanya penanda negasi tidak pada predikatnya (Sidharta, 2016). Proposisi tersebut mengandung satu pengertian menyangkal sesuatu yang dinyatakan oleh akal budi berupa putusan kita tidak mempedulikan. Kedua kalimat tersebut mengandung sebuah argumen yang berupa pendirian (claim). Temuan ini menunjukkan bahwa siswa sudah mampu menggunakan jenis proposisi positif dan proposisi negatif dalam karangan argumentasi siswa secara bervariasi. 


\section{Proposisi Berdasarkan Kuantitasnya}

Berdasarkan kuantitasnya dalam karangan argumentasi siswa kelas XI MAN 2 Wakatobi ditemukan proposisi berjenis (1) proposisi universal, (2) proposisi partikular, dan (3) proposisi singular. Pertama, proposisi universal dapat dijelaskan dengan contoh kalimat Semua mahluk hidup di bumi membutuhkan perawatan. Sebuah proposisi universal adalah proposisi yang subjeknya universal dan membenarkan atau mengingkari seluruh subjeknya (Martono dan Shodiq, 2018). Kehadiran quantifier sетиа dalam proposisi tersebut berfungsi sebagai penunjuk banyaknya satuan yang diikat oleh term subjek (Mundiri, 2014). Proposisi partikular dapat dijelaskan dengan contoh kalimat sebagian pelajar kurang memperhatikan pelajarannya. Proposisi tersebut menggunakan quantifier sebagian yang berarti satu bagian. Proposisi yang sifatnya partikular ini menunjukkan sebagian atau beberapa kelas yang menjadi cakupan dari term predikat disebut proposisi partikular (Martono dan Shodiq, 2018). Kehadiran quantifier sebagian dalam proposisi yang berfungsi sebagai penunjuk banyaknya satuan yang diikat oleh term. Proposisi singular dapat dijelaskan dengan contoh kalimat Kepala sekolah kami sudah menginstruksikan penerapan aturan sekolah dengan segala sanksi-sanksinya. Proposisi tersebut menggunakan subjek kepala sekolah kami yang berarti merujuk pada suatu jabatan tertentu yang menunjukkan jumlah satu orang saja yaitu kepala sekolah kami. Sebuah proposisi yang sifatnya singular ini menunjukkan satu orang saja yang menjadi cakupannya atau berkedudukan sebagai anggota kelas dari term predikatnya disebut proposisi singular (Martono dan Shodiq, 2018).

Proposisi universal, partikular dan singular tersebut berupa argumen yang ditentukan oleh luas wilayah seperti suasana universalitas, partikular, dan perseorangan (Goldsmith, 2006). Isi proposisi universal, partikular, dan singular biasanya diterapkan pada subjek, sementara luas subjek yang menyatakan keseluruhan dimasukkan ke dalam cakupan predikat (Poespoprodjo dan Gilarso, 2017). Kalimat-kalimat tersebut mengandung sebuah argumen yang berupa pendirian (claim), dan landasan (ground). Sebuah pendirian harus meneguhkan atau menyangkal suatu hubungan antara dua pernyataan (Poespoprodjo dan Gilarso, 2017; Sidharta, 2016). Temuan ini menunjukkan bahwa siswa sudah mampu menggunakan jenis proposisi universal, proposisi partikular, dan proposisi singular dalam karangan argumentasi siswa secara bervariasi.

\section{Proposisi Berdasarkan Kombinasi Kuantitas dan Kualitasnya}

Berdasarkan kombinasi kuantitas dan kualitasnya dalam karangan argumentasi siswa kelas XI MAN 2 Wakatobi ditemukan proposisi berjenis (1) proposisi universal afirmatif, (2) proposisi partikular afirmatif, (3) proposisi singular afirmatif, (4) proposisi universal negatif, (5) proposisi partikular negatif, dan (6) proposisi singular negatif. Proposisi universal afirmatif dapat dijelaskan dengan contoh kalimat, Semua pengguna jalan memiliki kewajiban untuk menaati peraturan lalu lintas. Sebuah proposisi yang sifatnya universal afirmatif ini menunjukkan seluruh lingkungannya dan masing-masing cakupannya tidak ada yang dikecualikan. Proposisi universal afirmatif ini mengikat atau mengakui semua subjek yang disebutkan (Martono \& Shodiq, 2018; Zaimul, 2000). Kehadiran quantifier sетиa dalam proposisi tersebut berfungsi sebagai penunjuk banyaknya satuan yang diikat oleh term subjek kepada permasalahan universal disebut proposisi universal (Mundiri, 2014). Proposisi partikular afirmatif dapat dijelaskan dengan contoh kalimat Kondisi sebagian umat Islam yang kita lihat saat ini sangat menyedihkan. Proposisi partikular afirmatif tersebut terdiri atas satu proposisi. Proposisi tersebut menggunakan quantifier sebagian yang berarti sebagian atau beberapa kelas yang menjadi cakupannya dan tidak semuanya. Sebuah proposisi partikular mengikat atau mengakui sebagian atau beberapa yang menjadi subjek yang berkedudukan sebagai anggota kelas term predikatnya disebut proposisi partikular afirmatif (Martono \& Shodiq, 2018; Zaimul, 2000). Kehadiran quantifier sebagian dalam proposisi yang berfungsi sebagai penunjuk banyaknya satuan yang diikat oleh term subjek kepada permasalahan partikular disebut proposisi partikular (Mundiri, 2014). Proposisi singular afirmatif dapat dijelaskan dengan contoh kalimat Indonesia merupakan negara yang memiliki iklim tropis. Proposisi tersebut menggunakan subjek Indonesia yang hanya merujuk pada salah satu negara saja yaitu yaitu Indonesia. Proposisi yang menunjukkan satu objek saja yang berkedudukan sebagai anggota kelas dari term predikat yang ditunjuk dengan jelas disebut proposisi singular (Martono \& Shodiq, 2018; Zaimul, 2000).

Proposisi universal negatif dapat dijelaskan dengan contoh kalimat Semua siswa tidak boleh meninggalkan lingkungan sekolah selama jam pelajaran berlangsung. Sebuah proposisi yang sifatnya universal negatif merupakan proposisi yang mengingkari semua subjek yang disebutkan (Martono \& Shodiq, 2018; Zaimul, 2000). Kehadiran quantifier semua dalam proposisi tersebut berfungsi sebagai penunjuk banyaknya satuan yang diikat oleh term subjek kepada permasalahan universal disebut proposisi universal (Mundiri, 2014). Proposisi partikular negatif dapat dijelaskan dengan contoh kalimat Sebagian orang muslim tidak berpegang teguh kepada alquran dan alhadis. Proposisi tersebut menggunakan quantifier sebagian yang berarti sebagian dari orang muslim. Sebuah proposisi partikular negatif ini menunjukkan sebagian atau beberapa kelas (orang) yang berkedudukan sebagai anggota kelas dari term predikatnya hanya sebagian saja disebut proposisi partikular (Martono \& Shodiq, 2018; Zaimul, 2000).

Proposisi singular negatif dapat dijelaskan dengan contoh kalimat Ketua Osis kami tidak menyampaikan laporan pertanggungjawaban akhir kepengurusan. Proposisi tersebut menggunakan subjek ketua kelas kami yang berarti merujuk pada satu orang yang menjabat sebagai ketua kelas. Sebuah proposisi singular negatif predikatnya mengingkari satu objek saja yang berkedudukan sebagai anggota kelas dari term predikat yang ditunjuk dengan jelas disebut proposisi singular negatif (Martono \& Shodiq, 2018; Zaimul, 2000). Sebuah pendirian yang menyatakan bahwa suatu hubungan term predikat menyangkal term subjeknya disebut proposisi negatif (Sidharta, 2016). Kalimat-kalimat tersebut mengandung sebuah argumen yang berupa pendirian (claim), dan landasan (ground). Isi proposisi universal, partikular, dan singular biasanya diterapkan pada subjek, 
sementara luas subjek yang menyatakan keseluruhan, sebagian dan singularitas dimasukkan ke dalam cakupan predikat (Poespoprodjo dan Gilarso, 2017). Temuan ini menunjukkan bahwa siswa sudah mampu menggunakan jenis proposisi berdasarkan kombinasi kuantitas dan kualitas dalam karangan argumentasi siswa secara bervariasi.

\section{SIMPULAN}

Berdasarkan pembahasan tentang jenis proposisi dalam karangan argumentasi siswa kelas XI MAN 2 Wakatobi ditemukan tujuh simpulan. Pertama, berdasarkan sumbernya, dalam karangan argumentasi siswa kelas XI MAN 2 Wakatobi ditemukan (1) proposisi berjenis analitis, dan (2) proposisi berjenis sintesis. Kedua, berdasarkan bentuknya, dalam karangan argumentasi siswa kelas XI MAN 2 Wakatobi ditemukan (1) proposisi berjenis tunggal, dan (2) proposisi berjenis majemuk. Ketiga, berdasarkan sifatnya, dalam karangan argumentasi siswa kelas XI MAN 2 Wakatobi ditemukan (1) proposisi kategoris, (2) proposisi hipotesis kondisional, (3) proposisi hipotesis disjungtif, dan (4) proposisi hipotesis konjungtif. Keempat, berdasarkan tingkat kepastian kebenaran (modalitas), dalam karangan argumentasi siswa MA ditemukan (1) proposisi berjenis modalitas mutlak, (2) proposisi berjenis modalitas kontingen, (3) proposisi berjenis modalitas mungkin, dan (4) proposisi berjenis modalitas tidak mungkin. Kelima, berdasarkan kualitasnya, dalam karangan argumentasi siswa kelas XI MAN 2 Wakatobi ditemukan (1) proposisi berjenis positif, dan (2) proposisi berjenis negatif. Keenam, berdasarkan kuantitasnya, dalam karangan argumentasi siswa kelas XI MAN 2 Wakatobi ditemukan (1) proposisi universal, (2) proposisi partikular, dan (3) proposisi singular. Ketujuh, berdasarkan kombinasi kuantitas dan kualitasnya, dalam karangan argumentasi siswa kelas XI MAN 2 Wakatobi ditemukan (1) proposisi universal afirmatif, (2) proposisi partikular afirmatif, (3) proposisi singular afirmatif, (4) proposisi universal negatif, (5) proposisi partikular negatif, dan (6) proposisi singular negatif. Hal ini berarti bahwa jenis proposisi dalam karangan siswa kelas XI MAN 2 Wakatobi cukup bervariasi. Semua jenis proposisi terdapat struktur argumentasi yang terdiri atas satu pendirian (claim). Selain itu, pada proposisi hipotesis kondisional dan proposisi modalitas mutlak terdapat dua struktur berupa pendirian (claim) dan landasan (ground). Pada jenis proposisi hipotesis disjungtif dan proposisi hipotesis konjungtif terdapat struktur yang keduaduanya berupa pendirian (claim).

Berdasarkan simpulan yang sudah dikemukakan dalam penelitian ini dapat diajukan dua saran. Saran kepada peneliti lanjutan, bahwa masih banyak aspek yang berhubungan dengan penelitian ini yang membutuhkan perhatian untuk diteliti. Untuk itu, penelitian lanjutan tentang proposisi yang sangat diperlukan untuk memperkaya teori-teori proposisi, logika, dan penalaran. Saran kepada pembaca, penulis menerima saran dan masukan yang konstruktif dari pembaca guna perbaikan untuk penelitian selanjutnya. Semoga penelitian ini dapat dimanfaatkan oleh pendidik, pengamat, atau peneliti lanjutan baik tentang proposisi, penalaran, struktur argumen, atau karangan argumentasi siswa.

\section{DAFTAR RUJUKAN}

Adian, D. G. \& Pratama, H. S. (2015). Teknik Berargumentasi: Berpikir sebagai Kecakapan Hidup, Logika Terapan. Jakarta: Prenadamedia Group.

Amaliah, R., Ghazali, A. S., \& Hasanah, M. (2015). Proposisi Puisi Karya Anak. Jurnal Pendidikan Humaniora, 3(1), 60-69.

Dawud. (1998). Penalaran dalam Tuturan Bahasa Indonesia Siswa Sekolah Dasar. Disertasi tidak diterbitkan, Universitas Negeri Malang, Malang.

Dawud. (2010). Pembelajaran Berargumentasi Tulis Bahasa Indonesia. Malang: Universitas Negeri Malang.

Demirezen, M. (2013). The Recognition of Extended Simple Sentences as a Teaching Writing Problem. Procedia - Social and Behavioral Sciences, 70, 560-566. https://doi.org/10.1016/j.sbspro.2013.01.093

Djoko, F. W. (2011). Logika. Jakarta: PT Indeks.

Goldsmith, B. E. (2006). A Universal Proposition? Region, Conflict, War and the Robustness of the Kantian Peace. European Journal of International Relations, 12(4), 533-563. https://doi.org/10.1177/1354066106069323

Ibrahimi, M. N. (2012). Logika Lengkap. Yogyakarta: IRCiSoD.

Kemendikbud. (2017). Model Silabus Mata Pelajaran Bahasa Indonesia SMA/MA/SMK/MAK. Jakarta: Kementerian Pendidikan dan Kebudayaan.

Keraf, G. 2010. Argumentasi dan Narasi (Komposisi Lanjutan III). Jakarta: Gramedia.

Martono, N., \& Shodiq, D. (2018). Dasar-dasar Logika: Sebuah Intisari Metode Berpikir Logis dan Kritis. Depok: Rajagrafindo Persada.

Miles, M. B. \& Huberman, A. M. (1994). Qualitative Data Analysis: An Expanded Sourcebook (2nd ed.). California: SAGE Publications.

Moltmann, F. (2013). Propositions, Attitudinal Objects, and the Distinction Between Actions and Products. Canadian Journal of Philosophy, 43(5-6), 679-701. https://doi.org/10.1080/00455091.2014.892770

Mundiri. 2014. (Logika). Jakarta: Raja Grafindo Persada.

Narimo. (2015). Proposisi dan Argumen dalam Diskusi Kelas Siswa SMP. Jurnal Pendidikan Humaniora, 3(4), 276-286.

Nurgiyantoro, B. (2016). Penilaian Pembelajaran Bahasa Berbasis Kompetensi. Yogyakarta: BPFE-Yogyakarta.

Poespoprodjo, W. \& Gilarso, T. (2017). Logika Ilmu Menalar: Dasar-dasar Berpikir Tertib, Logis, Kritis, Analisis, Dialektis. Bandung: Pustaka Grafika. 
633 Jurnal Pendidikan, Vol. 4, No. 5, Bln Mei, Thn 2019, Hal 626-633

Ranjabar, J. (2017). Dasar-dasar Logika: Sebuah Langkah Awal untuk Masuk ke berbagai Disiplin Ilmu dan Pengetahuan. Bandung: Alfabeta.

Setiawan, T. (2005). Kaidah Pelesapan dalam Konstruksi Kalimat Majemuk Bahasa Indonesia. Litera: Jurnal Penelitian Bahasa, Sastra, \& Pengajarannya, 4(1), 41-51. https://doi.org/10.21831/ltr.v4i01.4883

Sidharta, B. A. (2016). Pengantar Logika: Sebuah Langkah Pertama Pengenalan Medan Telaah. Bandung: Refika Aditama. Sumadi. (2013). Sintaksis Bahasa Indonesia. Malang: Asih Asah Asuh.

Suyitno, H. (2008). Hubungan Antara Bahasa dengan Logika dan Matematika Menurut Pemikiran Wittgenstein. Humaniora, 20(1), 26-37.

Zaimul. (2000). Epistemologi, Logika, dan Bahasa. Rausyan Fikr, 13(1), 1440-1449. 